\title{
MULHERES NO CHORO: A PARTICIPAÇÃO FEMININA À ÉPOCA DOS 100 ANOS DO GÊNERO
}

José de Almeida Amaral Júnior ${ }^{1}$

\section{RESUMO}

Este artigo aborda a histórica questão cultural da participação feminina na arte, mais especificamente no universo do gênero Choro, considerado a primeira música popular urbana instrumental do Brasil. O recorte para a presente análise foi dado sobre o período que abarca o decênio 1973 - 1983 quando, em 1977, comemorou-se o "Centenário do Choro". Dada a ocasião e a inédita exposição midiática, tornouse perceptível quanto o espaço de participação da mulher estava reduzido a breves atuações e, mais que isso, como o fato passou incólume, sem indignações, em meio às discussões saídas dos debates pertinentes à efeméride. O significado simbólico dessa naturalidade, dessa desatenção, quanto à deficiência da presença feminina em meio a uma expressão cultural brasileira, revela como as raízes patriarcais e machistas são determinantes e prejudiciais à liberdade das mulheres em sua atuação artística, profissional e como ser humano.

Palavras-chave: Música popular brasileira. Condição feminina. História social

Vivenciando uma ditadura, iniciada em 1964 com golpe de Estado, o Brasil durante a década de 1970 teve, em sua área cultural, a passagem da efeméride comemorativa dos 100 anos de nascimento do Choro, considerado o primeiro gênero musical instrumental urbano nacional.

Além do evento histórico em si, o período acabou por também trazer um momento de "resgate midiático" do gênero Choro, já que o mesmo apresentava uma participação deveras acanhada nos veículos de comunicação: rádios, TVs, jornais, revistas ou mesmo a indústria fonográfica que, há décadas, nada estavam atentos às suas produções. Estas sobreviviam verdadeiramente em mãos de abnegados grupos cultuadores, que chegavam a se definir de forma bem-humorada como "confrarias" ou "maçonarias", preservando-as em suas residências, em isoladas reuniões com parceiros e fãs, revelando novas criações ou, principalmente, procurando manter vivas na memória antigas composições.

O mercado, então, resolveu apostar algumas fichas nos tradicionais chorões. Pôs para funcionar suas engrenagens e o negócio reverberou bastante. Além dos espaços em programas de TV, houve um incremento de participação na produção de discos, partituras e shows, que culminou na realização de dois festivais nacionais televisados a partir de São Paulo, na criação de clubes de Choro por vários pontos do país e, até mesmo, na entrada do gênero em trilha de novela. Foi um boom, uma expansão. Em momentos mais eufóricos dessa conjuntura, alguns jornais chegaram a publicar debates entre críticos e

\footnotetext{
${ }^{1}$ Pós-Graduado Lato sensu em História: Arte, Patrimônio e Cultura do UNIFAI - Centro Universitário Assunção; mestre em Educação - Políticas pelo Centro Universitário Nove de Julho; especialista em Sociologia pela Escola de Sociologia e Política de São Paulo - FESPSP e bacharel em Ciências Econômicas pela Pontifícia Universidade Católica de São Paulo - PUCSP
} 
músicos envolvendo teses de "modernidade X tradição" nos aspectos estéticos sobre o Choro contemporâneo, discutindo os riscos de descaracterizações e problemas afins. Situações impensáveis tempos antes. "Choromania", conforme designação verificada na imprensa. Uma "revitalização" aparentava acontecer.

Porém, os interesses mercadológicos, que estimularam a divulgação, se dissiparam. Seus impulsos foram dirigidos a outras ofertas. O Choro, fechando os anos 1970, voltou a resistir nas mãos dos devotos que, contudo, sem dúvidas, tiveram ganhos com o período, pela chance de gerar novos laços e por ver a ampliação do número de admiradores, garantindo o ânimo à resistência e o findar do temor pelo desaparecimento do gênero, como se cogitava até há pouco.

Entretanto, com o boom ocorrido pela via dessas investidas, através da ênfase dos veículos de comunicação, resultando em várias produções, foi possível notar que o universo do Choro, um século após sua gênese, no geral, manteve a figura feminina reduzida a pequenas participações de realce. A mulher bem pouco apareceu em relevo. Isto, embora sabendo-se, por exemplo, que sem a presença fértil da pioneira pianista, compositora e maestrina Chiquinha Gonzaga (1847-1935), não lograria se iniciar construção de uma digna cronologia chorona. Mas não houve atenção ao tema como, por exemplo, aquela que se observou referente ao embate "modernização versus tradicionalismo" no Choro. Ou seja: foi uma questão menosprezada.

Passados os anos 1960, com o fortalecimento da urbanização, a liberação feminina, o advento de antibióticos e da pílula anticoncepcional, o fim da obrigatoriedade de autorização do marido para trabalhar, em pleno último quartel do século XX, as musicistas choronas ainda assim não haviam conseguido ampliar seu espaço, não haviam contemplado seu papel de maneira a equilibrar justa representação ao lado dos homens.

Desde o fim da década de 1960, problematizou-se mais o lugar e os direitos das minorias. Apareceu um novo e vivo olhar sobre a participação das mulheres na história. Especificidades foram discutidas, assim como seu reconhecimento político e social. A partir de então e, principalmente, nos anos 1970, notou-se o ingresso acentuado feminino no mercado de trabalho. E tal situação não aconteceu apenas pela deterioração dos salários reais, mas também pela dificuldade econômica, obrigando as pessoas a buscarem complementação da renda familiar, especialmente nos segmentos sociais menos favorecidos. Também registrou-se claro ingresso das camadas médias, de mulheres com maior instrução. Novas possibilidades de comportamento e consumo eram desejadas (BRUSCHINI, 1994). Destaque-se que durante a década de 70, o movimento feminista teve desenvolvidas suas "cores locais", sempre fustigado pelo regime repressivo ditatorial, somado às posturas reacionárias do machismo atávico. Anseios de maior protagonismo em meio aos riscos autoritários vigentes (DIMAMBRO, 2019).

Ao longo do tempo a sociedade impôs à mulher a esfera privada - dedicação ao lar, pouca instrução, reduzido acesso à escrita e leitura - e, quando muito, a circunscreveu a profissões como o magistério, que estabelece um paralelo ao papel de mãe e educadora, ou seja, a cuidadora da prole. Não 
era bem aceita em outras funções, caso dos exercidos nos espaços artísticos, entregues ao protagonismo masculino. Ela serviu, sim, incontáveis vezes, como inspiração artística, mas teve sempre dificuldades em produzir as suas próprias experiências. Tal preconceito resultou em prejuízo de grande monta. Fato que impacta evidentemente nos aspectos de expressão artística, o feminino na arte, e também na atuação dentro do mercado de trabalho. Claro, não apenas para as mulheres choronas, mas sim para as musicistas em geral. E é notável até agora.

Segundo a revista Rolling Stone, em 2017, dos "100 maiores artistas da música brasileira” apenas 16 são mulheres (SÊLA, 2019). Elas representam 14\% dos associados da União Brasileira dos 9 Compositores (UBC), a maior administradora de direitos autorais do país. Os seus valores médios arrecadados são 28\% menores que os masculinos. Elas são $8 \%$ dos músicos acompanhantes e $11 \%$ dos intérpretes (UBC, 2018): enormes discrepâncias em se considerando os dados quantitativos do governo que mostram, hoje, a população brasileira ser composta por 48,3\% de homens e 51,7\% de mulheres. Permanecer naturalizando tal discriminação e disparidade é sério entrave aos Direitos Humanos.

Em um ligeiro paralelo com o ambiente do Samba - que tem história imbricada com o Choro, não podendo se deixar de marcar que os cariocas viram ambos desabrocharem em casas lideradas por mulheres, as “Tias Baianas" no bairro de Cidade Nova -, nota-se que as dificuldades impostas a elas são similares. Por exemplo, importante compositora da Escola Império Serrano, Dona Ivone Lara (1922 - 2018), - em 1965 foi a primeira mulher a ter um samba-enredo na Avenida, assinando com Bacalhau e Silas de Oliveira (1916-1972) “Os Cinco Bailes da História do Rio" - precisou em várias de suas composições, ao longo da carreira, colocar nome de um homem para o Samba “acontecer" (PIRES, 2017). Barreiras permanentes. Subverter tal lógica, valorizando a mulher na música em todas as etapas da cadeia produtiva, são aspectos capitais neste assunto. É um exemplo, entre inúmeros, que merece meditação sobre a efetividade das condições de vida, da autonomia e da liberdade feminina para superar tal violência e desigualdade nas quais foram inseridas no decorrer da História.

Façamos, assim, uma breve reflexão sobre o tema, focando as mulheres choronas no festivo período do centenário do gênero. Iniciaremos por um apanhado geral sobre a trajetória do Choro. Depois, destacaremos o período da "revitalização" para, adiante, detalhar um pouco a condição das musicistas, no ambiente paulistano, em uma década, entre 1973 e 83, na criação da Rua do Choro, R. João Moura, bairro de Pinheiros.

\section{O CHORO GERMINA ENTRE O II IMPÉRIO E A REPÚBLICA VELHA}

Com a vinda para o Brasil em 1808 da família real portuguesa, refugiada das invasões napoleônicas, a cidade do Rio de Janeiro, capital colonial onde a corte se estabeleceu, foi nos mais variados aspectos palco de mudanças que impactaram seu quotidiano. Todo o grande território d'alémmar, na prática, deixava de ser uma fechada colônia de exploração e passava a se abrir para o comércio 
internacional ${ }^{2}$. A população da cidade até as vésperas da Independência, 1822, dobrou. Reformas urbanas foram executadas, novos prédios se ergueram. Foi reorganizada a burocracia pública, instituída uma Imprensa Real, a biblioteca real, uma escola de medicina, o Banco do Brasil, construiu-se o Teatro Real de São João. Após os conflitos europeus, em 1815 a coroa agiu a fim de consolidar a elegância cosmopolita, subsidiando a vinda de artistas franceses. O Brasil deveria ser reconhecido pelo seu caráter “civilizado” e pela “adesão à ideia de progresso" (SCHWARCZ, 1998). O Rio de Janeiro ganhou pompa.

Passado o Período Regencial (1831-1840)³, a estratégia política da antecipação da maioridade de Pedro II (1840) deu resultado e o país avançou em seu processo de nação independente. Assim,

na capital, durante os anos de 1840 e 1860, [...] se cria uma febre de bailes, concertos, reuniões e festas. A corte se opõe à província, arrogando-se o papel de informar os melhores hábitos de civilidade, tudo isso aliado à importação dos bens culturais reificados nos produtos ingleses e franceses (SCHWARCZ, 1998, p. 111).

Dentro deste contexto, as expressões locais típicas de música e dança como o batuque, o jongo e o lundu, desenvolvidos pelos negros, bem como a modinha, foram misturados aos ritmos e gêneros dançantes importados, casos da marcha, valsa, schottisch, habanera e polca. Por tais encontros/cruzamentos o Choro viria à luz. Ele nasceria, então, como um jeito de tocar, um certo abrasileiramento da interpretação dessas músicas estrangeiras. Foi uma nova produção mestiça local em um território cujo povo foi reinventado/recriado desde a renascentista "Era dos Descobrimentos" marítimos, com a transplantação da cultura lusa e a migração compulsória africana, que se uniram às gentes originárias, configurando-se num processo - conflituoso - de mistura permanente e estabelecendo a personalidade do Brasil como uma sociedade mestiça e sincrética nos trópicos, distinta das matrizes que lhe deram origem (RIBEIRO, 2006) e gestado sob objetivos mercantis.

A denominação "Choro" causa divergências: talvez possa ter sido gerada pela forma sentimental de execução dos instrumentos; por derivar de "xolo", um tipo de baile que reunia os escravos nas fazendas ou, ainda, por remeter a grupos de charamelas, um instrumento de sopro usado no período colonial. O fato é que as festas/reuniões com instrumentistas populares e o próprio conjunto de músicos passaram a ser conhecidos como tal. Aliás, o "grupo chorão" foi caracterizado como um "terno", a associação de um solista - podendo ser flauta, bandolim, clarineta, sax - mais dois instrumentos para harmonização, casos do violão e cavaquinho. O popular mulato Joaquim Antônio da Silva Callado Jr. (1848-1880), ele próprio exímio flautista, organizou, na década de 1870, um grupo de músicos, ficando

\footnotetext{
2 Em 16/12/1815 aconteceu a criação do Reino Unido de Portugal, Brasil e Algarves, com a área deixando de ser oficialmente colônia por ordem do então Príncipe-regente Dom João, futuro rei D. João VI (1767-1826).

3 Após o processo da Independência, o imperador D. Pedro I iniciou a organização do Estado brasileiro em sua gestão, $1822-$ 1931. Ele, então, abdicou em favor do filho, menor de idade, optando por voltar à Europa e lutar pela restituição do trono luso, tomado pelo irmão Miguel, à sua filha Maria da Glória.
} 
notabilizado como "Choro do Callado"4 (PINTO, 1978). Callado foi considerado, por diversos autores, "o pai do Choro" 5 . Desta maneira, se nos salões aristocráticos a música era tocada por conjuntos de câmara e pianistas, para os espaços populares eram os "paus e cordas" dos chorões que marcavam presença.

Ao longo do tempo, no amadurecimento dessa "forma de executar" as danças europeias rumo à uma condição de gênero musical ${ }^{6}$ - e de se tornar um símbolo de cultura brasileira ${ }^{7}-$, o Choro recebeu contribuições essenciais de nomes como os já citados Chiquinha e Callado, assim como de Ernesto Nazareth, Anacleto de Medeiros, João Pernambuco, Zequinha de Abreu, Luiz Americano entre outros. E teve, em Pixinguinha (Alfredo da Rocha Viana Filho, 1897-1973), uma referência básica, por ter convivido e aprendido com os antigos chorões e misturado isso com suas experiências na tradição afrobrasileira, na frequência às casas das tias baianas ${ }^{8}$, nos terreiros, na música rural e também por sua ampla bagagem profissional como músico, inclusive tendo viajado ao exterior em 1922, excursionando à França e Argentina, com seu grupo Os Oito Batutas (CABRAL, 1997). Pixinguinha já teria renovado e consolidado o Choro em final dos anos 1920 (SEVERIANO, 2008).

\footnotetext{
${ }^{4}$ O trio flauta - violão - cavaquinho (ou flauta, dois violões e cavaquinho, como no Choro do Callado) tem seu paralelo na Seresta, em que o canto é introduzido na realização musical, a "voz e corda", feito tanto por diletantes quanto por profissionais. Vale aqui destacar que o Choro cantado, propriamente dito, encontrou, ao longo do tempo, alguma polêmica resistência. Muitos acreditam que adaptações de letras às composições musicais geram descaracterização do gênero já que ele nasceu instrumental. Certos elementos de cromatismo, modulações ou saltos melódicos originais, por exemplo, poderiam ser empobrecidos para facilitar a performance dos vocalistas. Ver CAZES (2008).

${ }^{5}$ Especialmente após os estudos do maestro Baptista Siqueira, considerando a formação de seu conjunto e a singularidade de sua obra, desenvolvida no período 1867-1880, quando faleceu. Ver em SIQUEIRA, 3 Vultos Históricos da Música Brasileira. Rio de Janeiro: MEC, 1970.

${ }^{6}$ O termo gênero não apresenta uma definição consensual mas, conforme Janotti Jr e Sá, enfatizando o caráter sociocultural, apresenta três eixos: regras econômicas que envolvem práticas de consumo e endereçamentos dos produtos musicais; regras semióticas que abarcam os processos de produção de sentidos, intertextualidades e paratextualidades; regras técnicas e formais tais como as técnicas de execução e habilidades específicas, a valorização de certos instrumentos musicais, o ritmo, a harmonia, a melodia e as relações entre palavras e sonoridades (JANOT'TI JR. e SÁ, 2019).

${ }^{7}$ Durante muito tempo o choro foi tratado como "música de vagabundo", algo menor, diz o violonista e pesquisador Mauricio Carrilho. "Até o próprio nome sempre lhe foi negado. Ernesto Nazareth chamava de tango brasileiro e assim conseguia entrar nas casas das pessoas, ser aceito pelas famílias, tocado pelas moças prendadas” (DUARTE e BAIA, 1998, p. s/nº). No entanto, ao lado do Samba tradicional, inseparáveis na origem carioca, com quem dividiu participantes, o Choro se diferenciava dele e dos subgêneros existentes, posicionando-se no degrau mais nobre da hierarquia cultural local por demandar perpétuo aperfeiçoamento técnico, virtuosismo, aproximação com a erudição, o que lhe promovia alto rendimento simbólico (FERNANDES e PULICI, 2016). Aos poucos, assim, a condição pejorativa mudou. Heitor Villa-Lobos (1887-1959) frequentou rodas de choro em sua juventude. Ele foi considerado, ainda em vida, o maior compositor das Américas e dos maiores expoentes da música erudita no país. Entre 1920 e 1928, compôs um conjunto de 14 peças que foram denominadas "Choros". Em 1925, o "Choro no 5" recebeu dele o sugestivo subtítulo "Alma Brasileira" e é das mais consagradas partituras para piano (MUSEU VILLA-LOBOS, 2007). Obra prima, para Mário de Andrade. Também com esse título, "Alma Brasileira", em 1932, foi a vez da icônica Chiquinha Gonzaga publicar um conjunto de partituras de Choro para sax e flauta (DINIZ, 2011). Francisco Mignone (1897-1986) e Camargo Guarnieri (1907-1993), ambos paulistas e compositores nacionalistas eruditos, criaram Choro. Mais recentemente, desde 2008, o Clube do Choro de Brasília foi considerado patrimônio imaterial; em 2012, o Choro tornou-se na cidade do Rio de Janeiro patrimônio cultural e em 2018 patrimônio cultural imaterial do Estado. Sobre as questões de símbolos e identidade nacional ver ORTIZ, Renato. Cultura Brasileira e Identidade Nacional. SP: Brasiliense, 1994

8 A presença feminina foi fundamental para a cultura do samba e choro carioca se perpetuarem. Com as "tias baianas" ganharam o acolhimento que precisavam para sair da "marginalidade": eram elas famosas curandeiras, trabalhavam com ervas medicinais, também eram lideranças religiosas, além de eximias cozinheiras. Vão marcando seu espaço pelo tempo afora, então, como pastoras, passistas, madrinhas, carnavalescas, porta-estandartes, intérpretes e operárias do samba, papéis imprescindíveis para a permanência dessa cultura (LIRA, 2016).
} 
Com menção às primeiras décadas choronas, há um documento fundamental: as singelas memórias do carteiro, violonista e cavaquinista chorão apelidado “Animal”, Alexandre Gonçalves Pinto, que publicou a obra "O Choro - Reminiscências dos Chorões Antigos" em 1936, retratando centenas de músicos populares da belle époque na capital da República, funcionários públicos, pequenos comerciantes, instrumentistas de bandas. Em geral gente intuitiva, de rasa leitura musical, aprendendo de ouvido em seus espaços de sociabilidade: as rodas de Choro. O livro ganhou edição pela Funarte em $1978^{9}$.

O período de maturação do Choro como manifestação cultural coincide com a chegada da indústria fonográfica no Brasil, fato que se dá em 1902 por meio da Casa Edison, de Fred Figner, no Rio de Janeiro - inicialmente se estabelecendo através das gravações mecânicas ${ }^{10}$ e, em 1927, passando a ser feita através das gravações elétricas ${ }^{11}$ - e também da radiodifusão, iniciada com as comemorações do Centenário da Independência, 1922. Seria a "fase dourada" do Choro ${ }^{12}$ - cabe, aqui, um destaque: em tabela produzida por Fontenele, com base em 5 fontes publicadas, para mostrar o número de compositores atuantes entre fins do século XIX e início do XX, 60 chorões foram elencados. Apenas Gonzaga como mulher estava relacionada ${ }^{13}$.

Daí para adiante, discos e emissoras passam a requerer os chorões para acompanhantes de cantores, com fama crescente junto ao público ${ }^{15}$. É a ocasião de formação dos Regionais das Rádios, que mostravam sua qualidade artística Instrumental; porém, tinham seu espaço cada vez mais restrito frente à música cantada. Raramente o instrumental fazia sucesso. O Choro deixava de ser o protagonista

\footnotetext{
${ }_{9} \mathrm{Na}$ histórica obra, as figuras femininas tem mínimo protagonismo. Ao longo da brochura, soma-se algo em torno de 280 nomes de músicos. Mulheres, vemos em destaque apenas os nomes de Chiquinha Gonzaga, da violinista e cantora Lily S. Paulo, a cantora de lundus e modinhas Placida dos Santos, a organizadora de encontros e cantora de lundus Mariquinha Duas Covas, e as promotoras de "tocatas" Durvalina, da Rua do Bom Jardim, e a lavadeira Maria da Piedade (PINTO, 1978).

${ }_{10}$ As primeiras gravações de Choro foram feitas pelas Bandas da Casa Edison e pela Banda do Corpo de Bombeiros, liderada por Anacleto de Medeiros. A maioria dos gêneros registrados teve a prevalência da polca, seguida da valsa, do schottisch, do tango e do maxixe. Notam-se gêneros híbridos como polca-maxixe ou polca-choro, por exemplo. Atualmente, os temas intitulados tango, caso das composições de Ernesto Nazareth, são normalmente consideradas Choro (Coleção Memórias Musicais, 2002). Similar condição para as partituras impressas citadas anteriormente de Chiquinha Gonzaga, realizadas ainda em sua vida, ano de 1932. Várias das músicas foram antes concebidas, e algumas até publicadas, para piano, como polcas, habaneras e tangos, sendo reconsideradas para o álbum "Alma Brasileira" como Choros (DINIZ, 2011).

${ }_{11}$ A gravação elétrica melhora a qualidade de forma geral. Facilita a captação do som e sua reprodução. Os cantores de "pouca voz" poderiam se estabelecer, mesmo que os de vOz possante se mantivessem na ativa. Período de decadência dos selos nacionais e entrada para valer no mercado brasileiro das gigantes dos EUA, como Victor e Columbia. O processo incrementou a venda de discos e de aparelhos de reprodução (FENERICK, 2005).

12 Expressão do pesquisador carioca Ary Vasconcelos.

13 As fontes usadas por Fontenele foram: com pesquisas de José Silas Xavier, o LP "Chorando Callado" (1981); com análise de Humberto Franceschi, discos (78 rpm) da Casa Edison, "Memórias Musicais" (2002) e estudos de Maurício Carrilho e Anna Paes para "Princípios do Choro" (2003). Como apoio/auxilio, também o livro "Panorama da Música Popular Brasileira na Belle Époque", de Ary Vasconcelos (1977) e "Dicionário Cravo Albin de Música Popular Brasileira" (on-line). (FONTENELE, 2016, pp. 159-160)

$15 \mathrm{Na}$ década de 1920, o rádio era um meio de comunicação ligado às camadas altas da população. Tinha caráter educativo, com aulas, conferências e palestras. Isto começa a mudar durante os anos 1930, durante o governo Vargas, quando se inicia uma maior profissionalização do meio, chegada da propaganda e concomitante popularização. O número de emissoras se ampliou pelo território. O público passou a frequentar os auditórios e surgiram os astros radiofônicos, entre músicos e atores. No final dos anos 1930 as Rádios Mayrink Veiga e Nacional (RJ) tornavam-se referências no país. Ver sobre o assunto em CABRAL, Sérgio. A MPB na era do rádio. São Paulo: Moderna, 1996 e CALABRE, Lia. A era do rádio. Rio de Janeiro: Jorge Zahar Ed., 2002.
} 
de diversos ambientes musicais sociais para figurar em segundo plano. Ao mesmo tempo, o Samba ia se consolidando como sinônimo de identidade nacional ${ }^{14}$. Diz o pesquisador J. R. Tinhorão:

Até a década de 1930, a música brasileira não sofria tão brutalmente com a ação avassaladora da indústria cultural e ela era ouvida nas rádios, inclusive o choro [...] Os chorões, individualmente bons músicos profissionais, passaram a acompanhar cantores. E o choro ficou mais restrito ao ambiente amador: é a espontaneidade das rodas de choro (apud ROCHA, 2001, p. s/no).

Todavia, as décadas de 1930 e 40, ainda assim, apresentaram uma profusão de grandes 13 musicistas, que foram levados ao estrelato das emissoras e selos fonográficos. Exemplos: Zezinho (19041987), Gaó (Odmar Amaral Gurgel, 1909 - 1992), Copinha (1910-1984), Garoto (1915-1955), Dilermando Reis (1916-1977), Antônio Rago (1916-2008) e Laurindo de Almeida (1917-1995), todos da cena paulista, e ainda Benedito Lacerda (1903-1958), Luperce Miranda (1904-1977), Radamés Gnattali (1906-1988), Abel Ferreira (1915-1980), Raul de Barros (1915 - 2009), Jacob do Bandolim (1918 - 1969), Waldir Azevedo (1923 - 1980), Altamiro Carrilho (1924 - 2012), José Menezes (1924-2013), Canhoto da Paraíba (Francisco Soares, 1928 - 2008), entre outros. Então, de acordo com Ary Vasconcelos, depois do ano de 1950 haveria um vazio chorão denominado por ele de "vacas magras". Etapa que chegou a suscitar maus presságios ${ }^{15}$ para gente do meio, e que se estenderia até 1975 (VASCONCELOS, 1984), quando aconteceu o boom do gênero pelo seu reaparecimento midiático.

\section{OS ANOS 1970 E O “RESSURGIMENTO” DO CHORO}

No ano de 1977, mês de novembro, a capa do paulistano Jornal da Tarde, grupo O Estado de São Paulo, anunciava que além da Rádio e do Estúdio, a marca Eldorado passava a significar também uma companhia gravadora de discos. E, sintomaticamente, estreava com o LP "Revendo com a Flauta os

\footnotetext{
14 Tal fato se dá em meio a Era Vargas, período de 1930 a 1945, quando elementos culturais antes rechaçados pelas elites passaram por uma valorização - não sem conflitos - e a música popular foi um dos itens para a construção de uma pretensa identidade nacional. O samba é posto como catalisador dos novos mitos de formação, percebido e projetado na consciência coletiva pelo poder do Estado (SIQUEIRA, 2004). No Estado Novo (1937- 45) o subgênero "Samba-Exaltação" ganhou largo espaço, com suas letras ufanistas e arranjos sofisticados. Nessa conjuntura, o período conhecido como "A Era do Rádio" nota-se que acabou por conferir uma ideia de autenticidade musical aos anos 1930 e 40, forjando certa tradição musical carioca como "sinônimo de autêntica música brasileira", assim como reforçou um panteão de gênios, entre eles Pixinguinha e Noel Rosa, ligados ao universo sambista (NAPOLITANO, 2010, p. 60).

${ }^{15}$ Jacob do Bandolim, referência do Choro e herdeiro da "militância da tradição" de Lucio Rangel e Almirante, disse ao jornal O Tempo, em 1953, que em 10 anos o choro estaria extinto, caso as "interferências modernizantes" agissem sobre ele. Entre elas, elementos do jazz (NOBILE, 2014). Ortodoxo, certa vez disse: "Há dois tipos de chorões, o chorão de estante, que eu repudio, que é aquele que bota o papel para tocar choro e perde sua característica principal que é a improvisação e há o chorão autêntico, verdadeiro, aquele que pode decorar a música pelo papel e depois lhe dar o colorido que bem entender. Este me parece o verdadeiro, autêntico, típico chorão" (apud PETERS, 2005). O Choro não acabou, mas sofreu sem divulgação nos anos 1960. Altamiro Carrilho, célebre flautista, chegou a vender 12 de suas 18 flautas e destruir todos os seus troféus (BARAÚNA, 2015). Ainda, em 1995, o mesmo instrumentista passava por dificuldades financeiras, não tendo dinheiro para tratamento dentário, segundo NASSIF (2000). Equilíbrio pouco sustentável para a condição dos músicos populares. Por outro lado, Maurício Carrilho defende que, no período dos 1950/60, o choro se soltava para a improvisação usando diferentes formações, caso de Radamés com seu quinteto, ou a "Turma da Gafieira”, que gravava choros e sambas (DUARTE e BAIA, 1998).
} 
Bons Tempos do Chorinho" do flautista capixaba Carlos Poyares (1928-2004). "Este foi o ano do Chorinho. E do primeiro disco Eldorado", dizia a manchete. No mesmo diário, era encontrada na coluna de televisão a novela "Nina”, de Walter George Durst, dirigida por Walter Avancini e Fabio Sabag, TV Globo, de 27/06/1977 a 13/01/1978. Trazia composições de Chiquinha Gonzaga, Callado, Nazareth, Pattapio Silva, Pixinguinha, entre outros em sua trilha sonora. Nas páginas de espetáculos, o vespertino destacava o Projeto Pixinguinha, criado em 1977, com suporte da Fundação Nacional de Artes FUNARTE, tendo a proposta de fazer circular pelo país shows de música brasileira a preços acessíveis, como da dupla Abel Ferreira e a cantora potiguar Ademilde Fonseca (1921-1912), entre muitas outras coisas. Vivia-se o cume do boom do Choro.

A década de 1970 assinalou um momento de reaparecimento do Choro e de seus realizadores. O efeito disso foi um encadeamento de eventos que ocorreram pelo encontro da participação estatal com a iniciativa privada, resultando na ampliação dos espaços de divulgação em forma de espetáculos, gravações, escritos e ações institucionais. Alguns elementos contribuíram para esse contexto: a preocupação/percepção de pesquisadores e críticos sobre uma crescente influência da música estrangeira no país; a desatenção à tradição e à autenticidade nacional, fazendo coro com setores da sociedade cidadãos caçados, censurados, exilados - reprimidos pela vigência da ditadura do pós $1964^{16}$; além disso, conforme Margarida Autran (2005), o choro pode ter sido favorecido por ser música "sem letras", instrumental, o que o livrou de censura. Porém, segundo ela, também pode ter-se configurado como estratégia de reforço às bases populares do regime ditatorial, pelo viés nacionalista/ popular intrínseco:

\begin{abstract}
Quando Roberto Moura define o choro como a "antimúsica de protesto" e afirma que "certamente não será uma coincidência o fato de que, num momento em que todas as artes brasileiras estão vivendo um clima de tensão, a MPB ter-se encaminhado para a ressurreição de um gênero tipicamente instrumental - onde não é preciso dizer nada" (O Dia, novembro de 1977), ele está abordando apenas um lado da questão. Talvez o fato de o choro não encontrar problemas com a Censura tenha facilitado seu rápido acolhimento por parte do novo projeto cultural brasileiro. Mas não foi o fator determinante. Se em 1974/75 o governo decide promover formas espontâneas de cultura que, como o choro, sobreviviam de um modo marginal, buscando integrá-las ao mercado, é porque precisa de uma base de sustentação ideológica. E é nas manifestações culturais que já contam com uma base popular que ela será buscada. É preciso tapar o buraco cultural, "interpretando" os "anseios e aspirações" do povo e impondo-os de volta como novos padrões a serem adotados, em prol da preservação da "identidade cultural" do país. (AUTRAN, 2005, p. 81).
\end{abstract}

Este assunto do Choro, como elemento de "disputa" entre os nacionalismos de direita e de esquerda, deve ser tratado em outra ocasião, com a especificidade cabível ${ }^{17}$. O fato é que, para muitos, o

\footnotetext{
${ }^{16}$ Em plena Guerra Fria, o golpe de Estado de 1964 foi um ato de militares brasileiros, apoiado por parte da sociedade e do empresariado do país. Além disso, teve também a adesão do governo dos EUA. Ver o assunto em FICO (2008) e TAVARES (2013). Sobre influência cultural estadunidense sobre o país no século XX: "A Invasão Cultural Norte Americana", de Júlia Falivene Alves, Ed. Moderna (2004).

17 Uma curiosidade sobre as preocupações com a "preservação do Choro”. Diário do Congresso Nacional, 8 de maio de 1974 registra o Projeto de Lei N. 1.942 do Deputado Federal Maurício Toledo, ARENA SP. Dispõe sobre a obrigatoriedade de as
} 
show "Sarau" de Paulinho da Viola com o Conjunto Época de Ouro e o veterano paulistano Copinha (Nicolino Copia), produzido por Sérgio Cabral, pesquisador ligado à tradição musical carioca, foi considerado o marco desse despertar para o Choro - vide fala do chorão Deo Rian, no Jornal do Brasil (RJ), 21/08/1978 -, ao buscar mostrar o gênero em condição eclipsada à juventude. Não obstante, em agosto de 1973, a TV Cultura de São Paulo levou ao ar “As Muitas Histórias da MPB” e, na sequência, de 1974 até 76, "O Choro das Sextas-feiras”, com o Conjunto Atlântico, séries apresentadas por Júlio Lerner e conteúdo de J. R. Tinhorão. Ambas produções vencedoras do Prêmio APCA. Foi um espaço televisivo inigualável até hoje para o gênero. E a onda foi ganhando volume. Por exemplo, em 1975, fundou-se o Clube do Choro da cidade do Rio, efeito que logo se espalhou por outras localidades do Brasil. Estas entidades promoviam rodas, shows e até aulas para os interessados que passaram a se aglutinar mais. Houve ações como o "Projeto Concerto de Choro", pela Secretaria Municipal da Educação e Cultura carioca, que levou apresentações a escolas e praças públicas e o I Encontro Nacional do Choro, no ginásio do Anhembi, cidade de S. Paulo, junho de 1977. É preciso destacar também o papel da gravadora paulistana Marcus Pereira, oficialmente formalizada em 1974, que foi muito aplaudida pela crítica em virtude dos lançamentos realizados: 142 discos dedicados à música popular brasileira, instrumental e cantada, resgatando manifestações folclóricas e regionais, incluindo parcerias com universidades e instituições públicas, com espaço garantido ao gênero, onde publicou série de 6 LPs entre 1973-78, intitulada "Brasil, Choro", sem contar diversos outros lançamentos na mesma linha (CRUZ, 2016). O último grande momento instrumental do Brasil havia sido a bossa nova (BAHIANA, 2005).

Falou-se em "choromania". Época em que alguns dos chorões tradicionais ainda estavam vivos como Abel Ferreira, Copinha, Waldir Azevedo, Dino, Meira, Canhoto e a nova safra pode contatá-los. Disse o compositor e pianista Francis Hime (1939-) "Pode ser até choromania. O essencial é aproveitar os bons momentos" (ROMAGNOLI, 1977, p. 4). “Até Os Mutantes, o Vímana e outros grupos mais habitualmente ligados ao rock incorporaram o choro a suas apresentações” (AUTRAN, 2005, p. 86). O acordeonista paraibano Sivuca defendeu o recrudescimento do momento. Para ele "[Choro] até então era tido como uma submúsica" (ROMAGNOLI, 1977, p. 4).

Percebendo as ações que estavam atraindo o público, a indústria fonográfica aproveitou para ofertar títulos há tempos arquivados, assim como promover lançamentos frescos, porém, nem sempre com critério de qualidade (MILLARCH, 1977). Tinhorão comentou à época: “O choro vai ficar em evidência enquanto as multinacionais do disco não tiverem outro iê-iê-iê para nos massificar" (apud ROMAGNOLI, 1977, p. 4). E, como prova do sucesso mercadológico, os anos de 1977 - instituído

empresas de discos realizarem gravações com conjuntos musicais executantes de "choros" de, pelo menos, seis em seis meses, com quantidade não inferior a 10 mil unidades, devendo a empresa cuidar de sua distribuição e divulgação. Ele sentiu- se tocado pela matéria "São Paulo preserva o choro, um ritmo que Rio abandona" publicada pelo jornal O Estado de São Paulo e assinada por Adones de Oliveira. O político da base governista dos "anos de chumbo" indicava sua preocupação com nossa "verdadeira cultura" musical, que enfrentava as "famigeradas versões" e outros ritmos insistentemente gravados e lançados. Ele já havia realizado outro projeto visando preservar as bandas de música. Note-se que esta iniciativa deu-se antes do ápice do boom do Choro. 
como Centenário do Choro $^{18}$ - e 1978 tiveram dois festivais nacionais transmitidos pela televisão. O primeiro, intitulado "Brasileirinho" e o segundo, "Carinhoso". Todos com lançamentos discográficos.

Nestes eventos, ápice do boom, registrou-se o embate da - constante - questão envolvendo tradição X modernidade no Choro e a problemática: o que é possível se alterar/ transformar sem perder a identidade, o genuíno, o típico? Tomados pelas discussões, ambos festivais foram vencidos por realizações "convencionais": "Ansiedade", do pernambucano Rossini Ferreira, em 1977 e "Manda Brasa", do potiguar K-Ximbinho (Sebastião de Barros, 1917-1980), em 1978, curiosamente um instrumentista cuja carreira esteve bastante ligada à linguagem jazzística das big-bands. Todavia, destaquese, na edição 1977, a presença da composição “Choro Cromático”, de Benjamim Araújo, um fundador do Clube do Choro paulistano, com novidades harmônicas e melódicas e, ainda, "Espírito Infantil”, de $\mathrm{Mu}$ Carvalho, tecladista do conjunto A Cor do Som, que trazia dissonâncias, elementos incômodos para os padrões, e o recado: "Já é hora do choro evoluir, porque há 100 anos ele é feito da mesma forma" (ROMAGNOLI, 1977, p. 4). Seriam necessários alguns anos para estes elementos estéticos formais se tornarem menos tensos.

Em 1979, comentando o lançamento do LP do II Festival "Carinhoso", Tinhorão, da ala “ortodoxa", escrevia no Jornal do Brasil: "O Choro faz parte da luta pela libertação nacional" (TINHORÃO, 1979, p.4). No artigo, conclamava ao público para responder aos lançamentos de discos nesse segmento, apontando a importância para a sustentação das iniciativas. Dizia:

[...] uma faixa de mercado para esse tipo de música brasileira [...] não é fácil, considerando o interesse global das forças de ocupação econômico estrangeiras (ao interesse global, é claro, não convém prestigiar o som regional [...] Por tudo isso, é importante a resposta que o público possa dar a investimentos de afirmação nacional [...] (TINHORÃO, 1979, p. 4).

Ele assinalava, ainda, que o III Festival aconteceria no Rio de Janeiro, intitulando-se "Noites Cariocas", homenageando a cidade e Jacob do Bandolim. Porém, o projeto não se concretizou. A partir de então, iria se dar um refluxo no cenário. O mercado havia trabalhado o Choro como uma moda. Esgotou a fórmula. Foi trocado por outras possibilidades de lucro. Chegava a vez dos holofotes mirarem o "BRock" de Titãs, Barão Vermelho e Legião Urbana. Politicamente, a ditadura iniciaria a sua fase termina ${ }^{19}$. Contudo, nada seria como antes para os chorões.

\footnotetext{
18 Invenção da tradição. Alguns eventos que deram repercussão à data: por exemplo, o Jornal do Brasil (RJ) anunciava em 29/11/1976, para sua rádio, o especial "100 Anos do Choro" com Abel Ferreira, Altamiro e os Carioquinhas; o mesmo diário, JB, em 27/05/1977 noticiava para o Teatro Fco. Nunes (BH/MG) show "100 anos de Choro". No Municipal paulistano aconteceu o evento "100 Anos de Chorinho", em 03/04/1977. O jornal Luta Democrática (RJ), 28/06/1978, p. 7, comentou sobre o Centenário dizendo que marcava o $1^{\circ}$ Choro composto, Flor Amorosa (Callado), de 1877. Mesmo argumento do Jornal dos Sports (RJ) em 1/07/1978. Ambos repercutiam a chegada do II Festival Nacional, o "Carinhoso"; o JB em 24/08/1979, "100 Anos de Choro", série de apresentações no Planetário da Gávea, com Altamiro Carrilho. Curiosamente, "Flor Amorosa" é de 1880 e "Atraente”, de Chiquinha Gonzaga, é de 1877.

${ }^{19}$ A resistência à ditadura levou ao fim do Ato Institucional no 5; à formação em 1978 do Comitê Brasileiro pela Anistia, nos diversos Estados da Federação, pela anistia ampla, geral e irrestrita aos atingidos pelos atos de exceção praticados pelo regime
} 
Aconteceram eventos como o III e IV Concurso de Conjuntos de Choro da UFRJ em 1979 e 80. Desenvolvia-se, ainda, o Projeto Pixinguinha - que seguiu até 1997. Conjuntos importantes surgiram, como a Camerata Carioca, o Nó em Pingo D’Agua, o Água de Moringa e O Trio, na cena carioca; a Orquestra de Cordas Dedilhadas de Pernambuco; As Choronas, o Vou Vivendo, o Nosso Choro, todos paulistanos. Também em São Paulo, a prefeitura criava em 1983 a Rua do Choro, onde nos finais de semana reuniam-se, até $1989^{20}$, músicos amadores e profissionais para a realização de rodas e shows. Viram-se desenvolver cursos sobre o gênero em escolas como a EMESP - Escola de Música do Estado de São Paulo em 1989; em 1993 nascer o Grupo de Choro do Conservatório de Tatuí; em 2000 acontecer a criação da carioca Escola Portátil de Música. Produções independentes e pesquisas se multiplicaram. Novos clubes de choro surgiram pelo mundo. A internet facilitou os contatos e possibilidades. E, assim, foi se pavimentando o caminho até hoje.

Clube do Choro de São Paulo, festivais nacionais na TV e a participação feminina

O boom do Choro trouxe à baila diversas discussões na mídia de então: a introdução ou não de elementos externos do Jazz e do Rock; a presença da guitarra e do baixo elétricos na formação dos grupos. O Choro seria mesmo uma expressão de resistência nacional em meio a invasão cultural estrangeira? Foi usado também pela ditadura para compor sua base ideológica? Essas são algumas contendas a serem aprofundadas em outro momento. Mas nem músicos, nem críticos ou jornalistas tocaram na flagrante invisibilidade artística feminina no universo chorão.

Observa-se, aliás, que a construção da narrativa histórica “oficial” já apresenta, para começar, a figura de Joaquim da Silva Callado como o "pai do Choro". Ele simbolizaria, então, a miscigenação, o encontro do branco com o negro, do europeu com o africano no Novo Mundo, resultando em um cidadão letrado, compositor, líder e técnico sobre uma base instrumental "provavelmente intuitiva" 21. Professor de flauta do Conservatório de Música do Rio de Janeiro e Comendador da Ordem da Rosa. 70 obras compostas - a mais conhecida, polca "Flor Amorosa", foi publicada postumamente em 1880 - e com muita popularidade. Na somatória, ele seria a síntese do período de gestação do Choro. Foi amigo de Chiquinha Gonzaga, com quem tocou e para quem compôs a polca “Querida por Todos” (1869). Ela, por sua vez, mestiça, pianista, compositora, maestrina, foi professora, militante política, abolicionista e organizadora da Sociedade Brasileira de Autores Teatrais - SBAT, para defender os direitos artísticos. Em fevereiro de 1877, publicou sua primeira composição, a polca “Atraente”. Em novembro, a música já tinha 15 edições. Atuou pela valorização do violão. Criou a marcha de carnaval. Viajou para a Europa

\footnotetext{
e, também, às grandes greves do movimento sindical do ABC. Importantes fatos do período para intensificar o enfrentamento ao governo de exceção que acabou em 1985. Ver LAMOUNIER (2009).

20 O Governo do Estado reativou em 2001 a proposta da Rua do Choro, na rua General Osório, próximo à Loja Contemporânea, reduto de chorões, concomitante à $2^{\mathrm{a}}$ edição do Clube do Choro de São Paulo, tendo Izaías do Bandolim à presidência, ex-integrante do Clube original (ROCHA, 2001) Durou cerca de 6 anos. Em 2017, por iniciativa do prefeito Fernando Haddad, aconteceu a $3^{\mathrm{a}}$ edição do Clube, com sede no Teatro Arthur Azevedo, Mooca.

${ }^{21}$ Batista Siqueira em Tinhorão (1978).
} 
onde trabalhou como compositora. Produziu temas para mais de 70 peças e 2000 músicas em variados gêneros. Viveu de sua música (DINIZ, 2011).

Saltemos adiante. De volta a meados dos anos 1970. Encontramos, então, os esforços de organização para a fundação do primeiro Clube do Choro de São Paulo, tendo o Sindicato dos Jornalistas como sede. Na prática, após o lançamento da ideia

- registrada em um "Manifesto do Movimento pela Criação do Clube”, assinado por 130 pessoas, junho/ 76, aniversário de Laerte Coutinho, cartunista -, a ação efetiva deu-se a partir de um mapeamento dos grupos existentes na cidade e arredores, entre junho e outubro, sob os cuidados dos jornalistas Sergio Gomes “Serjão” e Oswaldo Luiz Vitta “Colibri” (SOUZA, 2009). De um início que contou com alguns universitários, militantes clandestinos partidários e jornalistas, o movimento se espalhou e ganhou a força dos mais variados entusiastas, anônimos ou não. Nessa diligência, tiveram a pianista Tia Amélia (Amélia Brandão Nery,1897-1983), como adesão n 000, para algo em torno de 400 sócios que viram, em 28/05/1977, finalmente ser criada a entidade. Shows passaram a ser promovidos em bares da cidade e também eventos especiais, como o acontecido no Teatro Municipal, 20/06/1977, com 15 grupos, incluindo vários "recém-descobertos", além de profissionais de rádio e TV que apresentaram o evento. Estas circunstâncias todas ajudaram a desembocar nos grandes festivais nacionais transmitidos pela TV Bandeirantes. O Clube em seus dois anos de atuação publicou artigos, fez gravações, reuniu documentação memorialística, lançou um LP em homenagem póstuma ao violonista Armandinho Neves e criou a I Rua do Choro, em 1978, na sede da Al. Jaú, 2000. Fechou suas atividades em 1979 (SOUZA, 2009). Sem dúvidas, teve um importante papel na difusão do Choro em geral pela função agregadora que exerceu, entre os musicistas e fãs locais, assim como pelos intercâmbios ao receber artistas de fora do Estado.

Miranda Bartira Nunes Souza, filha de um dos fundadores do Clube, Rodrigues Nunes, escreveu em seus valiosos estudos referentes a entidade o seguinte enunciado:

Músicos, grupos e colaboradores do Clube do Choro, de 1977 a 1979.

Os nomes estavam anotados em um caderno de endereços pertencente a Osvaldo Luiz Vitta, onde constavam todos os contatos do Clube do Choro de São Paulo. Encontramse aqui descritos como nesse caderno (SOUZA, 2009, p. 159).

Observam-se anotados no referido bloco 25 grupos e destacados 233 nomes a partir deles. Mulheres relacionadas foram: a pianista Tia Amélia; a cantora Ademilde Fonseca; a pianista Eudóxia de Barros; a pianista Lina Pesce; a flautista Yvone Melo Toledo, do Trio Brasília ${ }^{22}$; Luciana Rabello, de Os Carioquinhas; a cantora Celina; a percussionista Geni e a cantora Miti, ambas do Regional Guarujá e,

\footnotetext{
${ }^{22}$ Trio Brasília: Francisco Araújo: Violão / Ivone Toledo: Flauta / Ignácio de Oliveira: Cavaquinho. Ivone não seguiu carreira profissional após o período do Clube do Choro. Ela havia gravado um disco com o Regional Brasília, de Tatuí, antes do Trio. Com o trio também realizou um LP, "Pegando Fogo", de 1982, com 8 temas de Araújo, 2 de Ignácio e um de João Dias Carrasqueira. Ignácio tocou por muitos anos na noite paulistana, tornou-se professor e Francisco Araújo também lecionou (BLOG DO CHORO, 2006). Ivone atualmente dá aulas de flauta em escolas de música.
} 
por fim, Regina, percussionista do grupo Premeditando o Breque. A presença feminina constatada no montante foi de apenas 10 musicistas. O que significa menos de 5\% dos artistas em ação.

Claro que é preciso ponderar que alguns instrumentistas atuam em mais de uma formação, condição clássica entre os chorões. Entretanto, ainda assim, o quadro é evidentemente dramático.

Quanto aos aspectos burocráticos, a diretoria do Clube

Era composta por músicos, jornalistas, advogados, poetas e entusiastas em geral. [O presidente era o maestro Benjamin Silva Araújo] [...] Eloisa Marques e Elias Gagliardi, tesoureiros; [...] Apesar dos diversos títulos, não havia uma hierarquia rígida no comando do Clube. [...] cada um ajudava como podia (SOUZA, 2009, p. 70).

Uma componente entre os tesoureiros. Mais adiante, a estudiosa apresenta os Conselhos Fiscal e Consultivo. No primeiro, havia 6 homens e nenhuma mulher. No segundo, mais amplo, com 42 membros, estavam entre eles Ademilde Fonseca, Eudóxia de Barros e Celina Muylaert, violonista, esposa do então presidente da Fundação Pe. Anchieta (SOUZA, 2009, p. 70). Três mulheres para pensar a entidade. Isto constitui $7 \%$ dos participantes.

Entre os entrevistados do trabalho, o violonista e compositor cearense Francisco Araújo, dos primeiros a integrar o Clube, comenta a participação feminina no Choro. Ele afirma:

Mulher não podia tocar choro! Eu fiquei muitos anos para descobrir que "Corta Jaca" era composição de uma mulher, que era da Chiquinha Gonzaga, porque ninguém falava de mulher compositora, então o choro era só para homem, serenata era coisa para homem, mulher não participava de serenata. [...] Não participava de nada. Que coisa horrível! Mulher só pode ter filho e ficar picando couve na cozinha. [...] No Clube do Choro não tinha quase (SOUZA, 2009, p. 186)

Vale lembrar aqui que o Clube do Choro de São Paulo pretendia lançar discos como parte de seu Departamento de Arquivo e Memória, focando compositores paulistas, considerando levantamento de composições e obras inéditas. Da relação pensada, apenas o LP de Armandinho Neves foi feito, através do selo Clack, em 1978. Doze instrumentistas conceituados empunharam seus violões para as gravações. Nenhuma mulher entre eles.

Um acontecimento extraordinário foram os Festivais Nacionais do Choro, realizados em São Paulo no Teatro Bandeirantes, para profissionais ou amadores, com produções inéditas. No primeiro evento, o "Brasileirinho", 4 terças feiras em outubro/ 1977, com 12 apresentações por dia. O júri, presidido pelo produtor Marcus Pereira, foi formado por músicos, críticos e pesquisadores num total de 10 pessoas além dele. Nenhuma mulher. No ano seguinte aconteceu a segunda edição do evento, intitulada "Carinhoso", com as mesmas bases. Excetuando-se a exclusão do item "Choro com letra" (Luta Democrática, 28/06/1978, p. 7). Foi em outubro de 1978. Casa sempre lotada. O mesmo júri participou, ou seja, não teve presença feminina. 
Na edição de 1977, registre-se que, entre as finalistas, no tema "Homenagem ao Época de Ouro" (José Luís de Jesus), integrando o conjunto baiano Os Ingênuos, apresentava-se a flautista Elena Rodrigues Santos. Ela estudou na Alemanha, foi professora de música na Universidade Federal da Bahia e integrante da Sinfônica daquele Estado. Faleceu em 2017. Depois, na ocasião de 1978, destaque-se o fato que a composição vencedora, "Manda Brasa", de K-Ximbinho, foi defendida por ele e pelo Regional Rio Antigo, que trouxe, entre os seus membros, a flautista Rosane Volchan, estudante carioca de música na UFRJ e, posteriormente, artista plástica de carreira internacional ${ }^{23}$.

Dos Festivais da TV Bandeirantes foram extraídos LPs. No concurso de 1977, as semifinalistas foram exibidas em 2 discos do selo Marcus Pereira, intitulados "Choro Novo". No volume 1 temos “Chorinho para Um Rei” (Tia Mariinha), com a cantora Maria Marta, Tia Mariinha e o Regional de Evandro do Bandolim, bem como a interpretação de Eudóxia de Barros, com Pessoal da Guaranésia e orquestra, para “Tardio” (Eduardo W. R. Lima). No volume 2 do mesmo evento há a presença de Inah M. Sandoval com o tema "Soneca", interpretada pela pianista Lívia Sandoval Abrahão. Por sua vez, o selo Clack publicou “Brasileirinho - I Festival Nacional do Choro - As 12 Finalistas”. E documentouse a ausência total de compositoras entre os selecionados. No ano seguinte, 1978, a mesma gravadora, Clack, providenciou 3 álbuns para as eliminatórias do II Festival intitulado “Carinhoso". Foram anotadas trinta e seis músicas. Nenhuma delas de autoria feminina. E também não houve destaque nominal para mulher solista entre os seletos intérpretes.

\section{ANOS 1980}

Com o final do Clube do Choro, foi inaugurado o Bar do Choro, tocado pelo empresário Helton Altman, frequentador do Clube. Estabeleceu-se na Rua João Moura, ano de 1980. De acordo com Miranda Souza, foi adotada uma postura comercial, com horários e caches definidos para os músicos. Algo bem diferente do ambiente vivido no Clube original e sua característica sociabilidade, seu perfil amadorístico e peculiar maneira de organizar eventos, de trazer pessoas. Além disso, também gerou tensão a questão da nova "Rua do Choro", no quarteirão do bar. Conforme Colibri, Altman usou a ideia de Serjão, aproveitou a experiência que teve no Clube e virou "um empresário da coisa" (SOUZA, 2009, p. 144). Para Altman, a intenção seria dar continuidade e abrigar uma nova sede para o Clube. Apesar do formato, muitos músicos precisando de trabalho aceitaram tocar no empreendimento. De todo modo, o mercado musical paulistano se profissionalizava: não existiria mais a chance de jornalistas agendarem shows em bares para grupos, na base da camaradagem; tudo seria realizado por agentes, divulgadores e

\footnotetext{
23 Sobre Elena Rodrigues Santos, depoimento ao autor de um ex-colega de grupo Os Ingênuos, Ailton Reiner, para o "Programa Choro e Companhia - Música Instrumental do Brasil”, setembro/ 2019 e, referente a Rosana Volchan, ver página http://www.rosanevolchanoconor.com/resume.html, acessada em agosto/ 2019.
} 
empresas daí para adiante - e o Clube do Choro ficou como uma experiência nesse retrospecto (SOUZA, 2009). Foi uma aprendizagem.

Em conversas com este autor, Gustavo Simão ${ }^{24}$, o pandeirista Guta, fundador do Clube, membro do Conselho Consultivo e hoje radialista, destaca que a participação das mulheres naquele tempo teve figuras importantes de nossa música como as pianistas Clara Sverner, que atuou com o clarinetista e saxofonista Paulo Moura, e Eudóxia de Barros, que já nos anos 60 gravara Ernesto Nazareth, e esteve na fundação do Clube. Assim como Luciana Rabello e Maria José Carrasqueira, esta com formação clássica - assim como as pianistas Clara e Eudóxia -, e ocasionalmente interpretando choro. E completou: "Mas, aqui em São Paulo era só homem mesmo..." Corroborando as palavras do violonista Francisco Araújo, acima apontadas.

Pensando em esfera erudita, também se pode relacionar Odette Ernest Dias, flautista francesa que radicou-se no Brasil nos anos 1950, tocando na Sinfônica Brasileira e na Orquestra da Rádio MEC, entre outras. Enquanto era professora na Universidade de Brasília, tornou-se ativa participante da criação do Clube do Choro do DF, em 1977. Por outro lado, de autêntico berço popular, é preciso registrar também a figura fluminense de Nilze Carvalho, menina negra que estreou em disco aos 12 anos tocando Choro empunhando seu bandolim e, entre 1980 e 83, gravou 4 LPs do gênero pelo selo CID ${ }^{25}$.

Jane Silvana Corilov, Jane do Bandolim, hoje professora da EMESP, afirmou ao autor ${ }^{26}$ que quando começou, menor de idade, frequentava as rodas de Antônio D'Auria, líder do Conjunto Atlântico, em 1979, no bairro paulistano do Bom Retiro, levada pelo bandolinista Walter Veloso. Dali, foi convidada a tocar no Café Society. E, posteriormente, no Bar Brasileirinho, no Clube do Choro e no Vou Vivendo. "Eu fui uma novidade. Uma menina enxerida", garantiu ao autor. Até se firmar, sentiu preconceito por ser mulher e, ainda mais, bandolinista. Tempos à frente é que acabou conhecendo outras poucas musicistas daquele circuito: Kika Viana, Roberta Valente, pandeiristas, e Rose da Flauta. "Mas, na época, [só] tinha eu, né?"

Em setembro de 1998, o Jornal $A$ Tarde iniciava uma entrevista sobre ela dizendo "Prestes a lançar seu primeiro cd, Jane é a única mulher instrumentista de São Paulo que se dedica a manter viva a tradição do chorinho". Evidentemente um exagero, porém, sem ser descomunal. Jane diz "Tem muito músico fazendo choro em várias partes do Brasil, mas, sei lá, a gente não dá conta de divulgar. [...] [Está] perdido pelo país”. E, mais à frente nas respostas, fala sobre a questão do machismo no meio com contundência:

O choro é um meio predominantemente masculino, daí você já imagina. Ouvi muita resposta malcriada, grosseira, suportei cara feia, empresário mau-caráter, toquei em pé

\footnotetext{
${ }^{24}$ Entrevista durante o evento produzido pelo autor para o Centro Cultural São Paulo: “Era D’Auria - Roda de Memórias”, dias 18 e 25 de maio/ 2019, na Discoteca Oneyda Alvarenga.

${ }_{25}$ Para conhecer a trajetória da flautista Odete Ernest Dias verificar https://www.mis.ri.gov.br/blog/flautista-odette-ernestdias- abre-a-serie-depoimentos-para-a-posteridade/ acessado em setembro/ 2019 e sobre Nilze Carvalho ver LP "Choro de Menina", Rio de Janeiro, CID, 1980.

${ }^{26}$ Entrevista durante o evento produzido pelo autor para o Centro Cultural São Paulo: "Era D’Auria - Roda de Memórias", dias 18 e 25 de maio/ 2019, na Discoteca Oneyda Alvarenga.
} 
sozinha, tantas coisas. Engoli desaforos [...]Numa outra situação, um músico comentou: "Nossa! Eu toco há tanto tempo e nunca toquei no Memorial da América Latina. Como rolou para você tocar lá?" - É melhor não publicar a minha resposta (risos). O preconceito foi ficando mais acirrado à medida que fui conquistando destaque no meio [...] (JORNAL A TARDE, 1998, p. s/ no

Em sua iniciação, alvorada dos anos 1980, Jane revela o quanto havia de preconceito no meio. Além do pioneirismo no enfrentamento ao mundo masculino chorão paulistano, procurando espaço e reconhecimento de trabalho, Jane também foi das raras mulheres a liderar seu próprio grupo. No ano de 1993 organizou O Miado do Gato, por onde passaram só nomes respeitados do meio. Em 1998 foi intitulada "A Rainha do Bandolim Brasileiro".

\section{CONDIÇÃO FEMININA, HISTÓRICA DISCRIMINAÇÃO}

A mulher há muito sofre por um modelo opressor em que, aos homens, é efetivada a autoridade e poder ${ }^{27}$, e, a elas, é concedida a tradição dos papéis de mãe, esposa e dona de casa, todos envoltos em características culturalmente definidas por "femininas", tais como pureza, candura e resignação. São aprendizagens sociais que intervêm no curso do desenvolvimento desde a infância das meninas. Uma violência que não ocorre como agressão física ou coação exercida contra o corpo feminino, porém, é efetivada por outras dimensões das expressões de poder, especialmente a simbólica, ao se engendrar e compartilhar padrões socioculturais coercitivos em relação aos papéis sociais de cada indivíduo (BOURDIEU, 2002). Condição alimentada por aquilo que, na história, aparece como eterno e que não é mais que o produto de um trabalho de eternização que compete a instituições interligadas, tais como a Família, a Igreja e a Escola, realizarem. Um poder que se impõe e que se reproduz simbolicamente permeando as relações sociais: a preeminência do masculino sobre o feminino, perpetuando sua subordinação (BOURDIEU, 2002) ${ }^{28}$.

Na pesquisa de Margareth Rago, é possível observar que tais aspectos são também percebidos mesmo no início do século XIX, no interior do movimento operário, dentro das camadas populares, sendo a classe trabalhadora constituída em grande parte de mulheres e crianças. Houve grande atuação no sentido de fortalecer a intenção disciplinadora de deslocamento da mulher da esfera pública do labor e da vida social para o espaço doméstico. Reproduziam-se ali as exigências burguesas vitorianas de

\footnotetext{
${ }^{27} \mathrm{Na}$ Grécia Clássica, durante toda a vida, as mulheres ficavam sob a tutoria de alguém: do pai, do marido ou do filho, caso se tornassem viúvas. Ver CABALLERO (1999). No Novo Testamento bíblico está registrado em texto de Paulo "As mulheres sejam submissas ao seu próprio marido como ao Senhor; porque o marido é o cabeça da mulher, como também Cristo é o cabeça da Igreja” (Ef 5.22). São exemplos de fontes originárias da exclusão e do poder patriarcal.

${ }^{28}$ Dois temas ilustram bem essa condição: "Ai, que saudades da Amélia” (Ataulfo Alves/Mário Lago), disco Odeon, samba vencedor do concurso para o carnaval carioca de 1942, com Lago - advogado, ator e militante comunista - declarando à ocasião "Amélia' símbolo da mulher brasileira” e "A Volta do Boêmio", canção de Adelino Moreira, gravado quatro anos após ser composta, por Nelson Gonçalves, em 1957, selo RCA-Victor. Grandiosos e duradouros sucessos que reforçam o popular papel da mulher que lava, passa, cozinha e, meigamente, lhe resta o consolo e a alegria de saber ser a segunda opção após a natural necessidade do parceiro ser boêmio. (SEVERIANO e MELLO, 1997).
} 
"vigilante do lar". Desta forma, as mulheres tiveram obstaculizadas suas participações nas entidades de classe, nos sindicatos e no próprio espaço de produção. Segundo Rago, pouco importaram os vários artigos em que a imprensa operária cobrou maior participação feminina nos movimentos reivindicativos de classe. Na prática, todo o controle era masculino, com maior liberdade de circulação, acesso a informações e organização entre si. A estudiosa explica: "as mulheres deveriam participar enquanto filhas, esposas ou mães, isto é, na condição de subordinadas aos líderes. [...] Até 1935, a CGT francesa defendia que somente as viúvas e celibatárias deveriam trabalhar, pois "o homem deve alimentar a mulher" (RAGO, 1985, p. 64).

Rago comenta que a construção desse modelo de devoção e sacrifício pela família implicou em desvalorização profissional, política e intelectual. Uma imensa perda, porque parte do pressuposto que a mulher, em si, não é nada, tendo que esquecer-se de si mesma e realizar-se através do êxito do marido e dos filhos. No meio operário, fala-se também em "sexo frágil”, física e moralmente. Segundo ela, mesmo entre os anarquistas, "atribui-se o direito de liderança sobre as mulheres, seja devido à sua 'débil constituição física', seja devido à falta de combatividade que caracteriza a 'natureza feminina"' (RAGO, 1985, p. 67). Devem ser protegidas dos patrões, que só tem dois tratamentos para com elas: o "vocabulário indecente e vil da taberna e as delambidices rufianescas" (RAGO, 1985). Desde meados do século XX, a sociedade brasileira passou por várias transformações com crescimento urbano, massificação do ensino público, desenvolvimento industrial e ampliação nas possibilidades nos campos profissionais de trabalho. Nesse contexto, as relações de gênero manifestavam suas discriminações e aumentavam a tensão, já que eram questionadas as formas rígidas de papéis e atribuições entre homens e mulheres. Ampliou-se a participação feminina da classe média no mercado de trabalho. Sua voz passou a ser mais respeitada, embora seu desempenho continuasse "cercado de preconceitos e encarado como subsidiário ao trabalho do 'chefe da família', o homem” (CUNHA, 2001, p. 202).

Importante salientar que o mundo feminino, extremamente complexo, inclui questões de classe e de raça. Assim, por exemplo, em 1964, viu-se no Brasil forte participação da mulher na Marcha da Família com Deus pela Liberdade, envolvendo os setores mais tradicionais da sociedade. Em contrapartida, no início dos anos 70, mulheres estiveram participando de grupos clandestinos e ações armadas na guerrilha contra o golpe, década em que a causa feminista avançou no país frente ao chauvinismo $^{29}$. Contudo, as mulheres negras, em geral, estão sempre nos mais baixos patamares, estão

\footnotetext{
${ }^{29}$ Entre outras coisas houve a visita ao Brasil em 1971 de Betty Friedan, autora do best-seller "Mística Feminina", bíblia do feminismo dos EUA, e a ampliação das discussões sobre o tema, com publicações de jornais e debates em revistas e programas. Em 1979 a TV Globo levou ao ar a série "Malu Mulher" refletindo essas questões do quotidiano feminino urbano de então (DIMAMBRO, 2019). Vale também lembrar que, nos anos 1970, na Europa, um dos movimentos mais importantes que pressionou a luta pela visibilidade das mulheres que desempenham trabalhos em casa foi o "wages against housework", ou "salário para o trabalho doméstico", porque ele é desvalorizado, contudo é fundamental na sustentação das demais atividades e deveria ser remunerado (VIECELI, 2019).
} 
em desvantagem em relação aos outros grupos. A mulher branca ocupa posição superior à mulher negra socialmente ${ }^{30}$.

De todo modo, conforme a historiadora Mary Del Priore, Rose Marie Muraro, escritora e feminista, em “A Mulher na Construção do Mundo Futuro", 1966, demonstrou que a brasileira, habitante das grandes cidades, andava mais acelerada. Entretanto, vivia ainda com padrão de dupla moral: adotava medidas diferentes para educar meninas e meninos. Era uma "rainha do lar" que fazia vistas grossas aos "pulos de cerca" do marido. "A maternidade dotou a fêmea de uma estrutura emocional passiva" diziam os conservadores. Em 1974, a Revista Manchete, em pesquisa de opinião com mulheres de todo o país, mostrou que elas preferiam ser objetos dos homens a sujeitos na história (PRIORE, 2013). Contudo, além das permanências, havia muitos sinais de mudanças. Os contraceptivos, o mundo do trabalho em escritórios, lojas, fábricas, a escolaridade, lentamente rompiam o ciclo de dependência. Fatores que deram nova dimensão ao casamento. O mito da "rainha do lar" não escapou e teve que ser enfrentado. O que antes era varrido para "debaixo do tapete", geralmente pelas mãos da esposa, não se sustentaria mais. A lei do divórcio foi aprovada em 1977. Os descontentamentos vinham à tona. Nos anos 1980, caiam as realizações de casamentos. Os pares passaram a "se juntar". E a profissão ganhou importância na valorização pessoal (PRIORE, 2013).

Na década de 1970 a presença feminina ampliou ocupação nos espaços públicos. Caiu a taxa de fecundidade e subiu sua entrada no universo acadêmico. Facilitou-se a oferta de seu trabalho. Ampliavamse anseios de consumo. Aos poucos interesses se diversificavam e se liberavam ${ }^{31}$. Segundo Laís ABRAMO "uma das características da participação política da mulher no Brasil tem sido a sua escassa presença nos partidos políticos e em cargos eletivos (incluindo os legislativos) [mas] sua forte participação em movimentos e associações diversas" (2007, p. 269).

\section{O SUSSURRO FEMININO EM MEIO A TANTA MÚSICA}

No mundo das artes, mais especificamente na música popular, a história mostra que a presença feminina sempre sofreu intensa carga de rejeição, dados os modelos sociais expostos.

No Rio de Janeiro, mulher cantar no coro da igreja, por exemplo, só foi possível durante o século XIX, assim como começar a atuar em teatro lírico ou frequentar a área da plateia dos espetáculos

\footnotetext{
${ }^{30}$ Mulheres ganham hoje, em média, 21\% menos que os homens. As negras, especificamente, tem salários menores e menos oportunidades que as brancas. No Brasil a mulher negra sofre discriminação não só de gênero, mas também de etnia. Sobre a condição feminina, consultar dados da Agência Patrícia Galvão em https:/ /agenciapatriciagalvao.org.br/

${ }^{31}$ Mudança comportamental no ar: em 1978, no âmbito da música pop, as Frenéticas faziam sucesso em rádio e TV com "Eu sei que eu sou/ bonita e gostosa/ eu sei que você, me olha e me quer..." ("Perigosa" de Nelson Motta, Roberto de Carvalho e Rita Lee). Rita Lee, roqueira, já havia emplacado "Ovelha Negra" (1975): "meu pai me disse: filha/ você é a ovelha negra da família/ agora é a hora de você assumir/ e sumir" e faria, com Carvalho, em 1979, "Mania de Você": "Meu bem, você me dá água na boca / Vestindo fantasias, tirando a roupa / Molhada de suor de tanto a gente se beijar..." A música foi usada numa propaganda da Ellus Jeans, mostrando em closes um casal embaixo d'água se despindo enquanto o locutor dizia: "tire a roupa para quem você gosta". O mercado sinalizava o momento.
} 
(ANDRADE, 1992). Para as moças da sociedade, os salões imperiais do século XIX se configuraram como um espaço de articulação entre o público e o privado. Desenvolvia-se a arte de preparar ambientes de cordialidade. Ali lhes era concedida aparente liberdade para conversar, dançar, cantar e tocar piano. Ao longo do período monárquico, nos jornais apareceram anúncios com professoras de música. Atividade que ganhou prestígio social, talvez pela aproximação com o papel de mãe/orientadora. O piano era, então, um instrumento doméstico, símbolo da família reunida e próspera - a corte imperial foi chamada de “pianópolis" pelo poeta Araújo Porto Alegre (1856) e São Paulo também o foi, por volta de 1870 (Instituto Piano Brasileiro, 2019). Importante adereço para a formação feminina. Mas a atividade profissional de músico, propriamente dita, era papel masculino. A atuação feminina como atriz ou cantora não era de fácil aceitação. Em 1861, um periódico se referia a apresentação de uma "distinta professora de piano" no Theatro Lírico. "Distinta professora": ênfase à sua condição (FREIRE; PORTELA, 2013).

Escrevendo em 1992, Valéria Andrade dizia: “Até agora aceita-se indiscutivelmente afirmação que só a partir dos anos 50 e 60 deste século a mulher passou a atuar como compositora de Música Popular Brasileira” (ANDRADE, 1992, p. 240). Segundo Tinhorão, “até poucos anos atrás os compositores eram sempre homens" (apud ANDRADE, 1992, p. 242). Todavia, para a estudiosa, era necessário, o quanto antes, atrever-se a não considerar definitivas aquelas informações. Dentro de seu esforço, levantou os nomes de Dinorah de Carvalho e Joanídia Sodré, através de Mário de Andrade; Maria Guilhermina de Noronha e Castro, Madame A. de Matos, América Floripes de Castro Guimarães, Luísa Alvim, Alexandrina Maciel de Oliveira, Alice de Castro e D. Costa, através de Vasconcelos e, ainda, D.V.E.J. Carvalho, através da revista Bazar Volante, de 1865 (ANDRADE, 1992). Acreditou que haveria mais. E acertou.

Ao longo do final do Império e durante a República Velha seria observado um incremento no número de pianistas, formadas dentro e fora do país. Surgiram mais compositoras. Elas aparecem tocando e, inclusive, algumas recebendo premiações como Fanny Guimarães, Magdalena Tagliaferro e Guiomar Novaes. Ampliou-se a profissionalização. Nesse período, 106 compositoras vieram à luz. Compositoras e regentes vistas eram mulheres "bem nascidas". Foram 332 obras de mulheres musicistas dos salões aristocráticos cariocas, impressas por importantes editoras, reunindo 50 gêneros distintos, todas arquivadas na Biblioteca Nacional, conforme FREIRE; PORTELA (2013). Com tantas publicações, deveriam ser populares e consumidas. Reforçam a caracterização da condição feminina na sociedade: uma teimosa invisibilidade e controle que lhe são impostos.

Mónica Vermes, estudando a participação feminina na música da Belle Époque carioca, comenta que o registro da atividade das mulheres na historiografia é escasso; entretanto, observando outros tipos de fontes, nota-se uma presença significativa. Exemplo disso são os dados extraídos do Instituto Nacional de Música do Rio de Janeiro, elaborados por Leopoldo Miguez em 1897. Neles, a maioria dos alunos eram mulheres. Para a pesquisadora, "por considerá-las irrelevantes” (VERMES, 2011, p. 2) a história da música brasileira erudita não as registrou. Todavia, no seu entender, na prática, as mulheres “[...] 
acabavam funcionando como eixos de difusão musical, na educação dos filhos, nas atividades de lazer privado e semi-privado, como saraus realizados em casa, ou em recitais coletivos realizados em espaços públicos como amadoras" (VERMES, 2011, p. 1).

Assim, a atuação musical doméstica privada e semiprivada se constitui em um mini circuito de circulação de repertório e de formação de gostos cuja importância não pode ser ignorada. Um espaço com identidade própria. E é natural se conceber que esse meio abrigou enorme contingente de mulheres que estudaram no Instituto Nacional de Música, com força e capacidade de colocar repertórios em circulação (VERMES, 2011).

Vermes concentrou sua análise em livros de Vincenzo Cernicchiaro, Luiz Heitor C. de Azevedo e Bruno Kiefer. No primeiro, "Storia della Musica nel Brasile", de 1926, percebe que entre as atividades musicais, canto e piano se destacam. Das mais de 70 pianistas relacionadas, muitas se dedicaram à docência. Seis foram compositoras. E "é possível que algumas delas tenham se produzido em público apenas uma vez” (VERMES, 2011, p. 3). Em Luiz Heitor, na obra “150 Anos de Música no Brasil”, 1956, há destaque para os compositores. Chiquinha Gonzaga e Joanídia Sodré são as únicas mulheres mencionadas. Em "História da Música Brasileira", 1977, Kieffer omite a música popular e "semierudita”, criando a ausência de Chiquinha Gonzaga, a mais lembrada à época. Porém, como curiosidade, nota-se a "grande importância que ele parece dar para as esposas dos compositores, destacando sua cultura, formação, capacidade de criar um ambiente receptivo para reuniões domésticas e competência musical" (VERMES, 2011, p. 3).

Em São Paulo, no Conservatório Dramático e Musical (1906), período de Mário de Andrade como aluno de canto, 1914-18, calcula-se que seu público era de $80 \%$ para estudos de piano e $95 \%$ eram moças (AZEVEDO, 2006).

Verifica-se, então, com o tempo, com dificuldades, um gradativo crescimento de sua participação e reconhecimento. Especialmente no campo do erudito. O incremento na produção musical de mulheres encontraria correspondência adiante, na intensificação dos movimentos feministas que atravessariam o século XX, notadamente a partir dos anos 1960 (FREIRE; PORTELA, 2013).

Por outro lado, observamos a presença de cantoras populares na discografia e no rádio nacionais, principalmente a partir da era das gravações elétricas. Carmem Miranda foi o maior fenômeno musical nos anos 1930. Gravou muitos samba-choro. Entre as instrumentistas, no entanto, poucas haviam ido adiante com suas carreiras. Na maioria foram pianistas, como Tia Amélia, Lina Pesce (1913-1995) e Carolina Menezes (1916-2000), com considerável atuação no choro. E no campo da composição, a diminuta participação também se verifica, caso de Marília Batista, Almira Castilho, Dolores Duran, Maysa e Inezita Barroso ${ }^{32}$, entre as raras que se sobressaíram. A pesquisadora Valéria Andrade cita o caso de Sueli Costa, tentando atuar como compositora desde 1961. Durante anos teve seus trabalhos recusados

\footnotetext{
32 Em 1956 a paulistana Inezita Barroso gravou o LP "Inezita Apresenta", selo Copacabana, divulgando o trabalho das compositoras Babi de Oliveira, Juracy Silveira, Zica Bergami, Leyde Olivé e Edvina de Andrade.
} 
sob a alegação que "qualidade demais" atrapalha as vendas. Foi proposto a ela trocas de favores: sexo pela possibilidade de gravações. Também soube que acreditavam que Sueli Costa era um "nome frio", afinal: “Como é? Mulher compositora?” (ANDRADE, 1992, p. 243).

Desta maneira, dentro das Artes e Espetáculos, os profissionais da música representam um grupo predominantemente masculino. Inclusive no campo chamado "erudito" 33 . Embora, com o tempo, a discrepância tenha diminuído - especialmente após os anos 1960. As mulheres começavam a acelerar a desconstrução da cultural dominação masculina na música. Não obstante, após todas essas décadas, ainda tem muito a progredir, conforme observado.Considerações Finais

O universo artístico musical do Choro reproduziu por décadas o mais profundo machismo existente na patriarcal, conservadora e desigual sociedade brasileira, relegando o espaço feminino a um percentual mínimo de participação e, especialmente, derivado dos valores da música clássica, sobretudo pelo piano, instrumento que as "moças de família" eram autorizadas a tocar - tendo em vista seu reconhecido status aristocrático, como elemento de música camerística - e também utilizar para compor, notadamente para seu círculo íntimo. Fato que se comprova pelo número de publicações de composições desde meados do século XIX, nas “pianópolis” carioca (1856) e paulistana (1870), sem projeção das autoras e intérpretes, excetuando-se Chiquinha Gonzaga, que teve como companheiras, ao longo das décadas, neste rol de musicistas populares/ choronas, os restritos nomes de Tia Amélia, Lina Pesce e Carolina Menezes.

O período chamado de "revitalização", boom ou "choromania" dos anos 1970, não apresentou para a representatividade feminina nenhum avanço, nem sob o ponto de vista do número de novas intérpretes, de maiores instrumentistas participantes e, muito menos, como criadoras. E, em pleno suposto - "Ano do Centenário do Choro", 1977, momento do ápice do "ressurgimento" do gênero na mídia, não foi avistado nos principais veículos envolvidos qualquer preocupação sobre a pífia presença da mulher no cenário de então.

Gastou-se tinta com questões sobre interferências de elementos do jazz ou do rock, sobre o uso de instrumentos elétricos, se o Choro era uma bandeira nacionalista anti-invasão estrangeira no mercado musical, se o "revigoramento" era uma manipulação da inteligência ditatorial para se aproximar da população e tornar mais densa sua base de apoio. Entre outros assuntos. Porém, não se debruçou sobre esta injusta e preconceituosa situação. Nem conservadores e muito menos os progressistas, com tantos jornalistas, intelectuais, militantes e afins envolvendo-se. E os grandes festivais, simbolicamente, ainda premiaram o mais tradicional frente às incomodas novidades, que tiveram de esperar para conviver melhor com o meio chorão. Ausência de sensibilidade para o caso, em momento que a sociedade brasileira ampliava canais de discussão sobre a condição da mulher. Esse preconceito fica evidenciado

\footnotetext{
${ }^{33}$ Liliana R. P. Segnini, socióloga do trabalho, aponta que entre 2003 e 2011 variou de 87\% para 85\% a presença masculina branca no mercado da música como intérprete, regente, compositor, arranjador ou musicólogo. Um domínio atroz. Ver em Tempo Social - Revista de Sociologia da USP. v. 26, nº 1, 2014.
} 
nas palavras de Jane do Bandolim, neófita e única representante efetivamente chorona no cenário paulistano, na virada dos anos 1970/80, que teve de enfrentar com coragem insinuações maldosas, gozações, pouco caso, até ser reconhecida. Provas do fato vêm na memória do veterano pandeirista Guta: “aqui em São Paulo era só homem mesmo...” ou de outro tarimbado musicista, o violonista Francisco Araújo, presente durante toda a existência do original Clube do Choro: "Mulher não podia tocar choro! Eu fiquei muitos anos para descobrir que "Corta Jaca” era composição de uma mulher [...] [Mulher] Não participava de nada! No Clube do Choro não tinha quase...”, testemunhou. Em suma: ínfima participação no Clube original e nos grandes festivais do Centenário, seja como instrumentista, seja como compositora. Assim como na "Rua do Choro", fase R. João Moura, início dos anos 1980. Uma invisibilidade legitimada sem provocar indignação.

Não há dúvidas que, hoje, a dominação masculina da música é atacada pela força feminina. Esta, aliás, ainda muito aquém do equilíbrio desejado, conforme dados demonstrados. Todavia, por toda a contingência envolvendo o histórico episódio intitulado "100 Anos do Choro", o "primeiro gênero urbano musical instrumental brasileiro", um símbolo cultural do país, produto da miscigenação e do espírito de "antropofágica" brasilidade - que transformou as influências/ concepções externas do período imperial em "coisa nossa" -, não deixa de ser triste e assustador que o machismo empanasse a questão tornando-a um fato natural. Não fazendo brotar nenhuma espécie de cogitação de ação afirmativa. Caso muito significativo para pensar a sociedade brasileira contemporânea e as falhas no vigor do cumprimento dos Direitos Humanos.

Com uma equilibrada presença feminina, certamente o universo artístico do Choro seria enriquecido em possibilidades. Oxalá no futuro os festejos comemorativos do Bicentenário sejam surpreendentes pelas boas novas. - Ó abre alas, elas querem passar!

\section{Referências}

ABRAMO, Laís W. Inserção da Mulher no Mercado de Trabalho. Tese de Doutoramento. Sociologia. Faculdade de Filosofia, Letras e Ciências Humanas, Universidade de São Paulo, São Paulo, 2007 AMARAL JR, José de Almeida. Chorando na Garoa - Memórias Musicais de São Paulo. São Paulo: Fundação Theatro Municipal, 2013.

Conjunto Atlântico - Uma História de Amor ao Choro. São Paulo: Edição Paulistinha, 2017

ANDRADE, Valéria. Notas para um estudo sobre compositoras da Música Popular Brasileira

- Século XIX. Travessia - Programa de Pós-Graduação em Literatura, UFSC, Florianópolis, v. 23, n.23, 1991.

AUTRAN, Margarida. "Renascimento" e descaracterização do Choro. In: NOVAES, Adauto (org.) Anos 70: Ainda sob a tempestade. Rio de Janeiro: Aeroplano/ Editora Senac Rio, 2005. 
AZEVEDO, Elizabeth Ribeiro. Conservatório Dramático e Musical de São Paulo: pioneiro e centenário. São

Paulo: Revista Histórica. Edição n ${ }^{\circ} 16$ Ano 02 de novembro de 2006. Disponível em http://www.historica.arquivoestado.sp.gov.br/materias/anteriores/ Acesso setembro, 2019

BAHIANA, Ana Maria. Música Instrumental - O Caminho do improviso à brasileira. In: NOVAES, Adauto (org.) Anos 70: Ainda sob a tempestade. Rio de Janeiro: Aeroplano/ Editora Senac Rio, 2005

BARAÚNA, Mara. Três anos sem Altamiro Carrilho. Memória / Jornal GGN. 12/08/2015. Disponível em https://jornalggn.com.br/memoria/tres-anos-sem-altamiro-carrilho/ Acesso setembro, 2019

BLOG DO CHORO. Pegando Fogo. 15/07/2006. Disponível em http://blogdochoro.zip.net/arch2006-

$29 \quad 07-09$ 2006-07-15.html Acesso setembro, 2019

BOURDIEU, Pierre. A Dominação Masculina. 2a ed. Rio de Janeiro: Bertrand Brasil, 2002.

BRUSCHINI, Cristina. O Trabalho da Mulher Brasileira nas Décadas Recentes. Revista Estudos Feministas.

Rio de Janeiro: UFRJ, v. 27, $\mathrm{n}^{\circ}$ 2, 1994.

CABALlERO, Cecília. A Gênese da Exclusão: o lugar da mulher na Grécia Antiga. Revista Sequência.

Florianópolis: UFSC, v. 20, nº 38, 1999.

CABRAL, Sérgio. A MPB na era do rádio. São Paulo: Moderna, 1996 . Pixinguinha Vida e Obra. Rio de Janeiro: Lumiar, 1997.

CAZES, Henrique. O Choro Cantado: Um século de muitas tentativas e poucos acertos. In: Palavra cantada: ensaios sobre poesia, música e voz: MATOS, Cláudia (Org.) Rio de Janeiro: FAPERJ, 2008

CRUZ, Eduardo F. G. "Discos Marcus Pereira”: Disco Finalmente é Cultura! Dissertação de Mestrado. História. Faculdade de Ciências Humanas e Sociais, Universidade Estadual Paulista - UNESP, Franca, 2016

CUNHA, Ma Fatima. Homens e Mulheres nos Anos 60 e 70. Revista História: Questões \& Debates, Curitiba: UFPR, nº 34, 2001

DIÁRIO DO CONGRESSO NACIONAL. Projeto de Lei N. 1.942, Deputado Federal Maurício Toledo, ARENA SP, 8 de maio de 1974

DIMAMBRO, Nadiesda. Mulheres no Brasil dos Anos 70. Extraprensa - Cultura e Comunicação na América Latina, São Paulo, v. 12, n², 2019

DINIZ, Edinha. Alma Brasileira, coleção de Choros de Chiquinha Gonzaga. Portal Chiquinha Gonzaga, 2011 Disponível em http://chiquinhagonzaga.com/wp/alma-brasileira-colecao-de- choros-de-chiquinhagonzaga/ Acesso setembro, 2019

DUARTE, Oseas; BAIA, Paulo. Choro: Continuidade e Renovação. Revista Teoria e Debate. Fundação Perseu Abramo. São Paulo: Fev, $\mathrm{n}^{\mathrm{o}}$ 37, 1998. Disponível em https://teoriaedebate.org.br/1998/02/03/choro-continuidade-e-renovacao/ Acesso setembro, 2019

FENERICK, José A. Nem no Morro, Nem na Cidade. São Paulo: Annablume, FAPESP, 2005.

FERNANDES, PULICI. Gosto Musical e Pertencimento Social. Revista Tempo Social, EDUSP, São Paulo, v. $28, n^{\circ} 2,2016$ 
FICO, Carlos. O grande irmão - da Operação Brother Sam aos anos de chumbo. Rio de Janeiro: Ed. Civilização Brasileira, 2008.

FONTENELE, Ana Lucia. A Música Popular Urbana no Final do Séc. XIX e Início do Séc. XX no Brasil e sua influência nos arranjos de Pixinguinha. Resonancias, v. 20, nº 39, 2016

FREIRE, V.L.B.; PORTELA, A.C.H. Mulheres compositoras: da invisibilidade à projeção internacional. In: NOGUEIRA, I.P.; FONSECA, S.C. (Org.). Estudos de gênero, corpo e música: abordagens metodológicas. ANPPON - Pesquisa e música no Brasil. V. 3, 2013.

JANOTTI JR., Jeder; SÁ, Simone P. Revisitando a noção de gênero musical em tempos de cultura musical digital.

30 Galáxia - Revista do Programa de Pós-Graduação em Comunicação e Semiótica. PUCSP, São Paulo, n. 41, 2019.

JORNAL A TARDE. Jane do Bandolim. Entrevista.13/09/1998. In Sitio Bandolim.net. Disponível em http://www.bandolim.net/jane-do-bandolim-jornal-tarde-13091998 Acesso setembro, 2019

JORNAL DA TARDE. Este foi o ano do chorinho. E do primeiro disco Eldorado. Caderno Variedades, $09 / 11 / 1977$.

LAMOUNIER, Bolívar. Redemocratização. CPDOC/FGV (2009) Disponível em http://www.fgv.br/Cpdoc/Acervo/dicionarios/verbete-tematico/redemocratizacao Acesso setembro, 2019

LIRA, Suzana. As Mulheres no Samba. Itaú Cultural. 2016 Disponível em https://www.itaucultural.org.br/ocupacao/dona-ivone-lara/forca-do-feminino/?content_link=1

Acesso setembro, 2019

MUSEU VILLA-LOBOS. Contato com o Choro - Biografia. Rio de Janeiro, 2007 Disponível em http://museuvillalobos.org.br/villalob/biografi/contchor/index.htm Acesso setembro, 2019 NAPOLITANO, Marcos. A Música Brasileira na Década de 1950. Revista USP, São Paulo, no 87, 2010. NASSIF, Luís. Altamiro, o Flautista de Deus. Folha de S. Paulo, 13/02/2000.

NOBILE, Lucas. Arquivo de Jacob do Bandolim é Digitalizado. OESP, Cultura. 11/08/2014 Disponível em https://cultura.estadao.com.br/noticias/musica,arquivo-de-jacob-do-bandolim- $\underline{\text { e- }}$ digitalizado,1542207+\&cd=2\&hl=pt-BR\&ct=clnk\&gl=br. Acesso setembro / 2019

PETERS, Ana Paula. De ouvido no rádio: os programas de auditório e o choro em Curitiba. Dissertação (Mestrado) Universidade Federal do Paraná. Curitiba, 2005

PINTO, Alexandre G. O Choro - Reminiscências dos Chorões Antigos. Rio de Janeiro: Funarte, 1978 PIRES, Breiller. Teresa Cristina: "O samba reflete o machismo, mas de um modo menos hipócrita”. Caderno de Cultura. El País. 25/04/2017 Disponível em https://brasil.elpais.com/brasil/2017/04/19/cultura/1492633343 894848.html Acesso setembro, 2019

PRIORE, Mary del. Histórias e Conversas de Mulher. São Paulo: Planeta, 2013 
RAGO, Margareth. Do cabaré ao lar: a utopia da cidade disciplinar - Brasil 1890-1930. Rio de Janeiro: Paz e Terra, 1987

RIBEIRO, Darcy. O Povo Brasileiro. São Paulo: Companhia das Letras, 2006.

ROCHA, Janaína. Confraria do Choro - O gênero que toca a alma brasileira. Revista E. SESCSP, Maio, $\mathrm{n}^{\circ}$ 48, 2001 Disponível em

https://www.sescsp.org.br/online/artigo/900_CONFRARIA+DO+CHOROO+GENERO+QUE

\pm TOCA+A+ALMA+BRASILEIRA Acesso setembro, 2019

ROMAGNOLI, Luiz H. Choro, sim. Mas, até quando? Caderno B. Jornal do Brasil. 29/10/77

31 SCHWARCZ, Lilia Moritz. As barbas do Imperador. São Paulo: Companhia das Letras, 1998

SÊLA MUSICAL. A Proposta. (s/d) Disponível em http://mulhernamusica.com.br/quem- somos/ Acesso setembro, 2019

SEVERIANO, Jairo; MELlO, Zuza Homem de. A Canção no Tempo - 85 Anos de Músicas Brasileiras, Vol 1: 1901-1957. São Paulo: Ed. 34, 1997

SEVERIANO, Jairo. Uma História da Música Popular Brasileira. São Paulo: Ed. 34, 2008

SIQUEIRA, Magno Bissoli. Caixa preta: samba e identidade nacional na era Vargas - impacto do samba na formação da identidade na sociedade industrial, 1916-1945. Tese de Doutorado. Faculdade de Filosofia, Letras e Ciências Humanas, Universidade de São Paulo, São Paulo, 2004.

SOUZA, Miranda Bartira T.R.N. O Clube do Choro de São Paulo. Dissertação de Mestrado, Instituto de Artes/UNESP/SP, 2009

TAVARES, Camilo. O Dia que Durou 21 anos. Documentário, Pequi Filmes, 2013 TINHORÃO, J. R. Pequena História da Música Popular. São Paulo: Art Editora, 1978

UNIÃO BRASILEIRA DOS COMPOSITORES - UBC. Levantamento da UBC revela disparidades entre mulheres e homens. UBC Notícias Online. 07/03/2018 Disponível em http://www.ubc.org.br/publicacoes/noticias/9164Acesso setembro, 2019

VASCONCELOS, Ary. Carinhoso Etc. História e Inventario do Choro. Rio de Janeiro: Edição do Autor, 1984 VERMES, Mónica. As mulheres como eixo de difusão musical no Rio de Janeiro da Belle Époque. In: $7^{\circ}$ Encontro Internacional de Música e Mídia-Música, Memória: Tramas em Trânsito. São Paulo:

Musi-Mid, Vol. 7, 2011

https://www.academia.edu/1351203/As mulheres como eixo de difus\%C3\%A3o musical no Rio de Janeiro da Belle \%C3\%89poque Acesso setembro, 2019

VIECELI, Cristina Pereira. Feminização do trabalho. In Democracia e Mundo do Trabalho On line, 28/09/2019 Disponível em $\underline{\text { http://www.dmtemdebate.com.br/feminizacao-do-trabalho-e- }}$ arenovacao-das-lutas-pela-garantia-da-reproducao-

social/?fbclid=IwAR0C8Kx1H6dEOS4YvitAP2Bo7U-veR11evIL9Tf31CoOa'Tp'T3eVQY3s22r8

Acesso setembro, 2019 